7. Reprod. Fert. (1972) 30, 451-453

\title{
ANTIOESTRADIOL SERUM IN IMMATURE HAMSTERS
}

\author{
C. D. EKRE AND W. C. FOOTE \\ Utah State University, Logan, Utah 84321, U.S.A. \\ (Received 9th February 1972, accepted 1st March 1972)
}

Antioestradiol serum (anti- $E_{2}$ ) inhibited the uterine weight increases caused by HCG in immature mice and rats (Ferin, Zimmering, Lieberman \& Vande Wiele, 1968). When anti- $\mathrm{E}_{2}$ was injected into rats $2 \mathrm{hr}$ before an injection of $\left[{ }^{3} \mathrm{H}\right] \mathrm{E}_{2}$, Ferin et al. (1968) found reductions in uterine, ovarian and pituitary weights when these were compared with the weights of similar organs in rats not injected with anti- $E_{2}$. It is believed that anti- $E_{2}$ prevents $\mathrm{LH}$ release and may not necessarily affect the ovary, as shown when HCG caused ovulation even when anti- $\mathrm{E}_{2}$ was injected (Ferin, Tempone, Zimmering \& Vande Wiele, 1969). In rats which received PMSG and anti- $E_{2}$, ovulation was restored by HGG, again giving evidence that anti- $\mathrm{E}_{2}$ acts by inhibiting LH release (Ferin, Zimmering \& Vande Wiele, 1969).

The use of anti- $\mathrm{E}_{2}$ in hamsters has not been reported. This is an account of the use, in immature hamsters, of antibodies to oestradiol, produced in rabbits and turkeys.

After dissolving $2 \mathrm{mg}$ oestradiol-17 $\beta$-succinyl-BSA in $1 \mathrm{ml}$ saline with an equal volume of Freund's complete adjuvant, the mixture was homogenized. Weekly injections of $3 \mathrm{mg}$ antigen were given subcutaneously and intramuscularly to turkeys over a period of 4 weeks. Seven days later, they were bled once weekly for the following 3 weeks. Booster injections were given after a further 7 days. This booster injection and weekly bleeding routine was continued for about 5 months. Approximately $50 \mathrm{ml}$ blood were drawn from the major wing vein each time. A similar schedule was followed for the rabbits except that $1 \mathrm{mg}$ antigen in $1 \mathrm{ml}$ saline with $1 \mathrm{ml}$ adjuvant was used. Up to $40 \mathrm{ml}$ blood were obtained under a mild vacuum at each bleeding from the marginal ear vein.

The anti-BSA portion was absorbed with BSA, the end-point being determined with anti-BSA produced in a ram. There appeared to be no real differences between the turkey and rabbit antisera. Precipitin titres were at least $1: 1000$.

Forty-two immature female hamsters were randomly assigned to seven treatment groups (six hamsters per group), as shown in Table 1. The age of the hamsters at the beginning of treatment ranged from 30 to 33 days and the average weights ranged from 52 to $58 \mathrm{~g}$. Stimulation of oestrogen production, shown primarily by an increase in uterine weight, was effected by injecting HCG (1.25 i.u.) subcutaneously $2 \mathrm{hr}$ after the intraperitoneal injection of 3 or $6 \mathrm{mg}$ anti- $\mathrm{E}_{2}$ or normal serum (NS). This treatment was continued for 3 days and on the 4th day, the hamsters were exsanguinated under ether and the uteri and ovaries were removed and weighed. These organ weights were analysed by covariance, using Duncan's new multiple range test and factorial analysis.

The average body, uterine and ovarian weights after treatment are shown in 
TABLE 1

EXPERIMENTAL DESIGN OF ANTIOESTRADIOL SERUM TREATMENT IN HAMSTERS

\begin{tabular}{l|c|c|c}
\hline \multicolumn{1}{c|}{ Treatment } & $\begin{array}{c}\text { No. of } \\
\text { hamsters }\end{array}$ & $\begin{array}{c}\text { HCG } \text { i.u. } \\
\text { (given in } \\
0.33 \mathrm{ml} \text { ) }\end{array}$ & $\begin{array}{c}\text { Dose of normal } \\
\text { serum or antibody* }\end{array}$ \\
\hline None (control) & 6 & - & - \\
Normal serum & 6 & - & $0.5 \mathrm{ml}$ \\
Normal serum, HCG $\dagger$ & 6 & 1.25 & $0.5 \mathrm{ml}$ \\
HCG & 6 & 1.25 & $0.5 \mathrm{ml}$ \\
Anti-E2 (3 mg) & 6 & - & $3 \mathrm{mg}, 0.5 \mathrm{ml}$ \\
Anti-E2 (3 mg), HCG & 6 & 1.25 & $3 \mathrm{mg}, 0.5 \mathrm{ml}$ \\
Anti-E2 & 6 & 1.25 & $6 \mathrm{mg}, 1.0 \mathrm{ml}$ \\
\hline
\end{tabular}

* Weights are those of freeze-dried serum reconstituted in water in the amount indicated. All amounts, including HCG, are the amounts administered per day. Treatment continued once daily for 3 days.

$\uparrow$ Anti- $E_{2}$ (antioestradiol serum) or normal serum injected intraperitoneally $2 \mathrm{hr}$ before a subcutaneous injection of $\mathrm{HCG}$.

TABLE 2

AVERAGE BODY, UTERINE AND OVARIAN WEIGHTS OF HAMSTERS TREATED WITH NORMAL SERUM, HGG AND ANTIOESTRADIOL SERUM

\begin{tabular}{|c|c|c|c|c|c|}
\hline \multirow{2}{*}{ Treatment* } & \multirow{2}{*}{$\begin{array}{c}\text { Body } \\
\text { weight } \\
\text { (g) }\end{array}$} & \multicolumn{2}{|c|}{ Uterine weight $(\mathrm{mg})$} & \multicolumn{2}{|c|}{$\begin{array}{l}\text { Ovarian weight ( } \mathrm{mg} \text { ) } \\
\text { (sum of both ovaries) }\end{array}$} \\
\hline & & Unadjusted & Adjusted $\uparrow$ & Unadjusted & Adjusted \\
\hline $\begin{array}{l}\text { None (control) } \\
\text { Normal serum } \\
\text { Normal serum, HCG } \\
\text { HCG } \\
\text { Anti-E } 2 \text { (3 mg) } \\
\text { Anti-E } E_{2}(3 \mathrm{mg}), \text { HCG } \\
\text { Anti-E } 2(6 \mathrm{mg}), \text { HCG }\end{array}$ & $\begin{array}{l}56 \cdot 0 \\
55 \cdot 7 \\
52 \cdot 7 \\
51 \cdot 8 \\
57 \cdot 3 \\
58 \cdot 2 \\
54 \cdot 0\end{array}$ & $\begin{array}{r}97.5(40.2 \text { to } 173.6) \ddagger \\
75.0(48.5 \text { to } 114.0) \\
152.0(65.2 \text { to } 287.9) \\
142.5(78.5 \text { to } 238.7) \\
115.5(76.6 \text { to } 197.4) \\
93.0(48.7 \text { to } 144.1) \\
78.6(60.0 \text { to } 130.9)\end{array}$ & $\begin{array}{r}93 \cdot 6^{\mathrm{b}} \\
72 \cdot 6^{\mathrm{b}} \\
163 \cdot 0^{\mathrm{a}} \\
156 \cdot 4^{\mathrm{a}} \\
106 \cdot 0^{\mathrm{b}} \\
79 \cdot 9^{\mathrm{b}} \\
83 \cdot 3^{\mathrm{b}}\end{array}$ & $\begin{array}{l}29.8(25.2 \text { to } 32.0) \\
28.5(19.2 \text { to } 48.3) \\
36.0(24.3 \text { to } 52.7) \\
31.3(16.2 \text { to } 37.9) \\
31.3(25.0 \text { to } 40.0) \\
24.5(17.6 \text { to } 32.5) \\
27.5(22.1 \text { to } 31.2)\end{array}$ & $\begin{array}{l}30 \cdot 0 \\
28 \cdot 6 \\
35 \cdot 5 \\
30 \cdot 6 \\
31 \cdot 8 \\
25 \cdot 2 \\
27 \cdot 2\end{array}$ \\
\hline
\end{tabular}

* See Table 1 and text for full descriptions and abbreviations.

$\dagger$ Significant differences from Duncan's new multiple range test. Adjusted weights are for constant body weight. $P<0.05$ values not bearing the same superscript letter. $P \approx 0.05$ for 163.0 versus 106.0 .

$\ddagger$ Range in parentheses.

\section{TABLE 3}

TREATMENT INTERACTION OF UTERINE WEIGHTS OF HAMSTERS*

\begin{tabular}{c|c|c|c}
\hline \multicolumn{1}{c|}{ Treatment } & Anti- $E_{2}$ & Anti- $E_{2}+H C G$ & Averages \\
\hline Normal serum & 75.03 & 115.53 & 95.28 \\
Normal serum + HCG & 142.03 & 78.65 & 110.64 \\
& 108.83 & 97.09 & 102.96 \\
\hline
\end{tabular}

Dose of anti- $E_{2}$ with or without HCG was $6 \mathrm{mg}$. See text for abbreviations.

$$
\text { * Interaction }(P<0.01) \text {. }
$$


Table 2. The administration of 1.25 i.u. HcG increased uterine weight from an average of $83.1 \mathrm{mg}$ (average adjusted to body weights for control and NStreated hamsters) to an average of $159.7 \mathrm{mg}$ (average of adjusted weights for HCG and HGG plus NS-treated hamsters). When 3 and $6 \mathrm{mg}$ freeze-dried anti- $\mathrm{E}_{2}$ serum (reconstituted) were injected $2 \mathrm{hr}$ before the HCG injection, the uterine weight increases due to HCG were negated $(159.7 \mathrm{mg}$ versus 78.9 and $83.3 \mathrm{mg}$, respectively). The ovarian weight of $29.3 \mathrm{mg}$ for the average of the control and NS-treated hamsters was increased to $33.1 \mathrm{mg}$ for the average of the HCG and HGG plus NS-treated hamsters, but decreased to $26.2 \mathrm{mg}$ for the average of the 3 and $6 \mathrm{mg}$ anti- $\mathrm{E}_{2}$-treated hamsters.

The analysis of covariance for uterine weights (adjusted to constant body weight) showed a highly significant treatment difference $(P<0.01)$ and a highly significant regression (i.e. much of within-treatment differences was explained by the regression of uterine weight on body weight; $P<0.01$ ). Ovarian weight differences were not statistically significant. The coefficient of determination for the adjusted analysis was $42.8 \%$ on uterine weights and $25.2 \%$ on ovarian weights.

Duncan's new multiple range test was run on the adjusted uterine weights. The results are shown in Table 2 from which it can be seen that HCG caused significant weight increases over controls or NS-treated hamsters. When anti- $\mathrm{E}_{2}$ was used with HCG, weights were not significantly changed from controls, NStreated or anti- $\mathrm{E}_{2}$-only-treated hamsters.

Interaction was determined by factorial analysis, in which case the design was modified as the $2 \times 2$ system shown in Table 3 . This allowed optimum interaction measurement with a minimum of confounding. Results showed a highly significant treatment interaction $(P<0.01)$ on uterine weight but not on ovarian weight changes. The slight increase in uterine weight over the control and NS-treated hamsters caused by the anti- $E_{2}$ treatment (with no HCG) resulted in a higher interaction value than would otherwise have been true. This can readily be seen by a simple plot of the interaction table. The interaction shows that anti- $\mathrm{E}_{2}$ with HCG significantly depressed uterine weights over the increase elicited by HCG with the antiserum.

Results indicate that anti- $\mathrm{E}_{2}$ effectively negates the uterine weight increases elicited by HCG in immature hamsters.

The oestradiol-17 $\beta$-succinyl-BSA was kindly supplied by the National Cancer Institute, NIH, Bethesda, Maryland.

\section{REFERENCES}

Ferin, M., Tempone, A., Zimmering, P. E. \& Vande Wiele, R. L. (1969) Effect of antibodies to $17 \beta$ estradiol and progesterone on the estrous cycle of the rat. Endocrinology, 85, 1070.

Ferin, M., Zimmering, P. E., Lieberman, S. \& Vande Wiele, R. L. (1968) Inactivation of the biological effects of exogenous and endogenous estrogens by antibodies to $17 \beta$-estradiol. Endocrinology, 83, 565 .

Ferin, M., Zimmering, P. E. \& Vande Wiele, R. L. (1969) Effects of antibodies to estradiol-17 $\beta$ on PMS-induced ovulation in immature rats. Endocrinology, 84, 893. 